have remained almost neglected in this direction. The present communication provides an account of some medicinally important orchids from India with their biological status and suggests both in situ and ex situ conservation measures for their sustainable management in the country.

\title{
Plan de manejo para la conservación de Cattleya quadricolor Lindl. en el Valle del Cauca, Colombia
}

\author{
Guillermo Alberto Reina-Rodríguez ${ }^{1,2^{*}} \&$ N. H. Ospina-Calderón ${ }^{3}$ \\ ${ }^{1,2}$ Consultor, Fundacion Gaia, Cali, Colombia; ${ }^{2}$ Departamento de Biología Vegetal, Universidad de \\ Barcelona, España; ${ }^{3}$ Programa de Ecología, Fundación Universitaria de Popayán, Colombia \\ *Autor para correspondencia: guireina@hotmail.com
}

Cattleya quadricolor es endemica a Colombia, presente en solo 3 departamentos (Valle del Cauca, Quindío y Risaralda), categorizada como EN en el libro rojo de plantas de Colombia (Calderon et al, 2007), y es una de las 22 especies de flora con mayor amenaza en el Valle del Cauca. Con este estudio, se generó el mapa de distribución actual y potencial de C. quadricolor, se evaluaron las condiciones ecológicas y demográficas en su habitat, y se identificaron las amenazas y fuentes de presión para su plan de manejo. Un total de $3.000 \mathrm{~m} 2$, fueron medidos, distribuidos en parcelas de $50 \mathrm{~m} \times 2 \mathrm{~m}$, en los que árboles y arbustos con DAP mayor o igual a $2,5 \mathrm{~cm}$ que hospedaran C. quadricolor fueron censados. Se contaron los individos sobre los forófitos detallando, estado reproductivo, número de pseudobulbos, altura sobre el forófito, angulo, posicion del forófito, entre otros. Los resultados demuestran la presencia de la especie en 16 municipios con un área de extensión de presencia de 234.359 Has. comprendidas entre los 930 y $1.450 \mathrm{msnm}$. Se demostró que $C$. quadricolor es más abundante al interior del bosque (55\%) que en árboles aislados (16\%) y sus densidades oscilan entre de 260 a $1.180 \mathrm{Ind} / \mathrm{Ha}$. Cattleya quadricolor crece sobre 20 tipos de forófitos, sin embargo 4 de ellos A. excelsum (37\%), G. ulmifolia (26\%), F. insipida (12\%) y E. ulei (7\%) y representan el $82 \%$ de la preferencia de esta especie. Se concluye que la estrategia de conservación in-situ debe incluir un incremento de la cantidad y la calidad del hábitat a través del manejo de sus cuatro principales forófitos, la consideración de las variables aqui medidas, el desarrollo de un protocolo de propagacion in vitro para su reintroducción, así como la disposicion de exedentes en viveros comerciales para restar presion en campo.

\section{Characterization of Brassolaeliocattleya Raye Holmes 'Mendenhall' - putatively transformed for resistance to Cymbidium mosaic virus}

\author{
Nyan Stillwell ${ }^{1}$, Heather McCafferty ${ }^{2}$, Yun J. Zhu² \& Ingelia White ${ }^{1 *}$
}

'Department of Natural Sciences, University of Hawaii - Windward Community College, 45 - 720 Keaahala Road, Kaneohe, HI 96744, USA; ${ }^{2}$ Hawaii Agriculture Research Center, 94 - 340 Kunia Road, Waipahu, HI 96797, USA; *Author for correspondence: ingelia@hawaii.edu

Orchids are infected by more than 50 different viruses. Infected plants bloom less efficiently, lack vigor, and produce lower-quality flowers than healthy plants. One of the most important viruses, with worldwide distribution, is Cymbidium mosaic virus (CyMV). It is a single-stranded, RNA virus belonging to the group of rod-shaped potexviruses. In previous research, a Brassolaeliocattleya orchid was transformed with the coat protein gene from Cymbidium mosaic virus using an Agrobacterium-mediated method. The aim was to improve resistance of the orchid to CyMV. Protocorm-like bodies of Brassolaeliocattleya Raye Holmes 'Mendenhall' were used. A full-length coat protein gene of CyMV was cloned into a vector, which 
also contained kanamycin resistance for the selection of transformants. The coat protein was inserted under control of a $C a M V 35 S$ promoter in an anti-sense orientation. Putative transformants were selected for four months on media containing $25 \mu \mathrm{g} / \mathrm{mL}$ Geneticin Disulfate (G418). The objective of the present study is to further investigate and characterize the putative transgenic lines, which have been selected for antibiotic resistance. Molecular characterization of transformants is ongoing. Micropropagation is being carried out to multiply the transformed plant material. Plantlets will be used to develop an in vitro inoculation assay to test the resistance to CyMV. Future work will investigate the resistance of these lines to the Cymbidium mosaic virus.

\section{Pestiferous scale insects on native epiphytic orchids in south Florida: a new threat posed by exotic species}

\footnotetext{
LaWrence W. ZetTler ${ }^{1 *}$, JenNifer A. ZetTler ${ }^{2}$, Larry W. Richardson ${ }^{3}$, Haleigh A. Ray ${ }^{1,4}$, John P. McCormick ${ }^{1,5}$, Andrew L. Stice ${ }^{1} \&$ Ian Stocks ${ }^{6}$

${ }^{1}$ Department of Biology, Illinois College, 1101 West College Ave., Jacksonville, IL 62650, USA

${ }^{2}$ Department of Biology, Armstrong Atlantic State University, 11935 Abercorn St., Savannah, GA 31419, USA

${ }^{3}$ Florida Panther NWR, U.S. Fish \& Wildlife Service, 3860 Tollgate Blvd., Naples, FL 34114, USA

${ }^{4}$ Current address: Department of Entomology and Nematology, University of Florida, Gainesville, FL 32611, USA

${ }^{5}$ Current address: Department of Biological Sciences, East Tennessee State University, Johnson City, TN 37614, USA

${ }^{6}$ Division of Plant Industry, Florida Department of Agriculture \& Consumer Services, Gainesville, FL 32614, USA

*Author for correspondence: 1wzettle@mail.ic.edu

In 2009, phytophagous insects (Hemiptera: Coccidae, Pseudococcidae) were collected from the inflorescences of the ghost orchid, Dendrophylax lindenii, at an isolated natural site in Collier Co., Florida, surrounded by an urban area. During the next two years, additional surveys were carried out in more remote orchid-rich habitats to determine if, and to what extent, other native epiphytic orchids were infested. Within the Florida Panther National Wildlife Refuge in 2010, 29 of 46 orchids sampled at one site (Cochran Lake) harbored three species of exotic scales: orchid pit scale (Asterolecanium epidendri Asterolecaniidae), brown soft scale (Coccus hesperidum, Coccidae), and boisduval scale (Diaspis boisduvalii, Diaspididae). Heaviest infestations were noted on Epidendrum amphistomum, E. nocturnum, E. rigidum, and Prosthechea cochleata.

The follow-up study the second year (2011) was then expanded to include Fakahatchee Strand State Preserve. A total of 1,726 orchids spanning 10 taxa were surveyed at seven locations. Boisduval scale was detected on $2.3 \%$ of the orchids from six of the ten orchid species in both the Florida Panther NWR and Fakahatchee Strand. Prosthechea cochleata and E. amphistomum appeared to be most vulnerable to this scale, with infection totals of $5.8 \%$ and $2.1 \%$, respectively. Of 44 scales collected from the 39 orchids, $27 \%$ hosted hymenopteran parasitoids in various stages of development. The presence of $D$. boisduvalii adds an additional burden to state-endangered orchid populations and indicates that resource managers may need to expand management approaches to include plant-parasitic insect control.
} 